\title{
Sustainability of the urban water system using renewable energy resources
}

\author{
Nikola Knezović, M.Eng.C.E. \\ nikola.knezovic@gf3.sum.ba \\ Željko Rozić \\ University of Mostar, Faculty of Civil Engineering, Ph.D C.E. \\ zeljko.rozic@gf.sum.ba
}

\begin{abstract}
The aim of the research is to present the overall and significant impact of the urban water system on the environment, i.e. environmental protection in the context of increasing the use of renewable energy sources, and how such energy sources affect climate change in general. Renewable energy sources include: wind energy, water energy, solar energy, hydrogen energy, geothermal energy, biomass energy, tidal energy, wave energy, cold energy from space and others. The application of the principles of sustainable development leads to the need to use renewable energy sources, improve their technical characteristics and functioning, and find new methods and technologies to finally abandon the use of non-renewable energy sources. To this end, it is necessary to pursue a policy based on strategic planning and the use of an integrated approach in the operation and management of urban water systems.
\end{abstract}

Key words: urban water system, water supply, drainage, wastewater treatment, renewable energy sources, climate change

\section{Održivost urbanog vodnog sustava korištenjem obnovljivih izvora energije}

Sažetak: Cilj istraživanja je prikaz cjelovitog i značajnog utjecaja urbanog vodnog sustava na okoliš, odnosno zaštitu okoliša u kontekstu povećanja korištenja obnovljivih izvora energije, te kako takvi izvori energije utječu na klimatske promjene općenito. U obnovljive izvore energije ubrajaju se: energija vjetra, energija vode, energija Sunca, energija vodika, geotermalna energija, energija biomase, energija plime i oseke, energija valova, energija hladnoće iz svemira i druge. Primjena načela održivog razvoja dovodi do potrebe za korištenjem obnovljivih izvora energije, usavršavanjem tehničkih karakteristika i funkcioniranja istih, te pronalaženjem novih metoda i tehnologija za konačno napuštanje korištenja neobnovljivih izvora energije. U tu svrhu nužno je voditi politiku koja je temeljena na strateškom planiranju i korištenju integriranog pristupa u upravljanju i gospodarenju urbanih vodnih sustava.

Ključne riječi: urbani vodni sustav, vodoopskrba, odvodnja, pročišćavanje otpadnih voda, obnovljivi izvori energije, klimatske promjene 
Knezović, N., Rozić, Ž.

Sustainability of the urban water system using renewable energy resources

\section{INTRODUCTION}

Water is a key element of life on our planet. Without clean and drinkable water, all ecosystems on earth are disrupted, which has a direct impact on human health and quality of life. Water is also an important input parameter for the economic development of settlements and society as a whole. Unfortunately, pollution of waters, their drying up and inadequate wastewater drainage are just some of the problems that are leading to an increasingly drastic reduction in the amount of fresh water in the world. Water reserves are disappearing every day, and climate change and environmental pollution are further aggravating and accelerating this process.

This problem is especially evident in cities, which consume huge amounts of water and have a drastic effect of reducing and polluting water resources. Consequently, sustainability of settlements and the environment requires control of the urban hydrological cycle. The control is carried out by the urban municipal water system. Urban water system management is an important segment of any city's development. The socio-economic condition of the urban environment, its sustainability and productivity depend on the state and level of development of the urban water system. Adaptation to climate change has become the subject of numerous research papers. Large amounts of information, studies and reports on topics such as climate projections, vulnerability assessment or practical adaptation possibilities are available as a result. However, the problem is the lack of guidelines for decision-makers at the local level who wish to proactively prepare and adapt to climate change.

\section{SUSTAINABILITY OF THE URBAN WATER SYSTEM}

In 1987, the UN General Assembly defined the term "sustainable development" as development that meets the needs of the present generations without compromising the ability of future generations to meet their own needs. Agenda 21 recognizes that water resources are at the core of sustainable development and therefore requires that they be managed on the basis of sustainability principles [8].

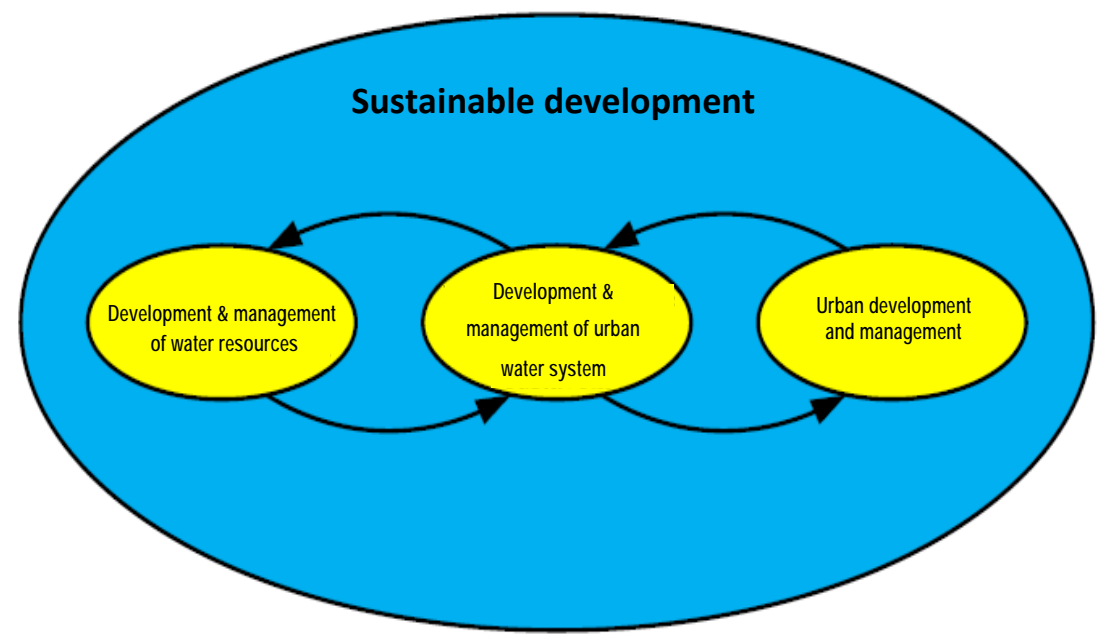

Figure 1. Sustainable management and development of the urban water system [4] 
Knezović, N., Rozić, Ž.

Sustainability of the urban water system using renewable energy resources

Abstracting increasingly larger amounts of water to meet the needs results in an increase of energy consumption at the same time. The concept of integrated management, in which the same importance was given to reducing needs (losses) and abstracting new quantities, was developed as a response to the reduction of available water resources and increase of supply costs. Much the same happened with energy, the consumption of which increased proportionally to the increase in water consumption [4]. Due to the high operation costs and financing problems of such systems, the systems became unsafe and increasingly threatened the sustainability of human life and work in urban environments. For this reason, it was necessary to carry out measures to strengthen sustainability [4]. Today, the management of the water supply system must include an analysis of the operation of the water supply system, improvements in reliability and savings in labor costs, as well as the possibility of influencing the environment and the standard of living of users. All this must be given the same importance as economic analysis, which ultimately satisfies the concept of an integrated approach. [4]

\section{RENEWABLE ENERGY SOURCES AND URBAN WATER SYSTEMS}

Water and energy are usually managed separately, despite the existence of many complex links between them. Water is used in the production of energy from almost all major sources, while on the other hand, energy is needed for the operation and functioning of water supply, drainage and wastewater and stormwater treatment systems as well as for heating water in households and the like [9]. The connections between water and energy are becoming increasingly stronger, especially in the context of climate change. To properly respond to the challenges of the $21^{\text {st }}$ century, a more integrated approach to water and energy management will be required. The first step toward greater integration is to improve our understanding of the relationship between these resources and the degree to which they depend on each other.

On the other hand, at a time when many cities are trying to reduce greenhouse gas emissions to mitigate climate change, intensive energy use of classic water infrastructure can be a drawback. In planning mitigation and adaptation actions, cities must keep the connection between energy and water in mind, to reduce the likelihood of unintended impacts. For example, the excessive water consumption of bioenergy crops is one of the main reasons cited by those who oppose their use as part of mitigation strategies. There are many sustainable water management options that have the added advantage of reducing energy consumption, although in some situations more decentralized solutions can actually increase energy consumption, highlighting the need for constructive dialogue between water and energy managers. A more sustainable approach to water management involves not only integrated management of the different elements of the urban water cycle, but also the coordination of actions with other urban management sectors, which can help identify synergies but also address conflicts. 


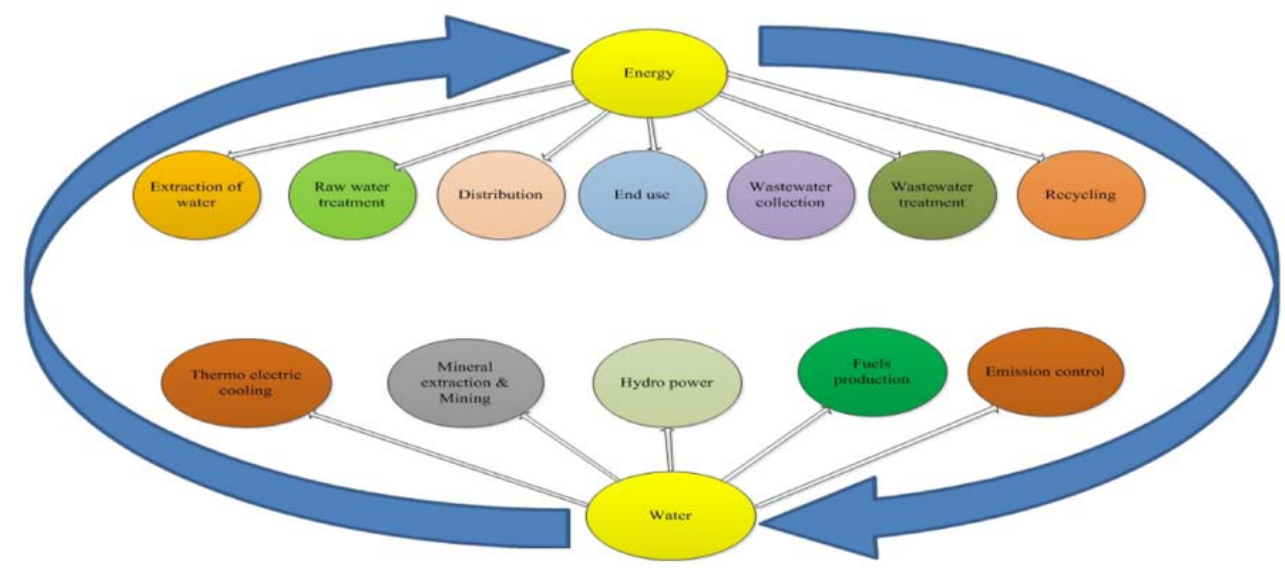

Figure 2. Connection between water and energy [16]

It has been registered in the literature that on average about $7 \%$ of global electricity production is accounted for urban water systems, while $3 \%$ of global electricity consumption is accounted for water pumping in the water supply system [16]. Analyzing the available data in specific places, like, say, California, where most drinking water is obtained by pumping from underground, even higher values can be obtained, thus in California water pumping accounts for as much as $7.0 \%$. In general, we can say that pumping water from underground compared to pumping from surface sources requires about $30 \%$ more energy [16].

However, the figures depend on many different factors such as topography, depth of pumping, technology, condition of the infrastructure and the like. It is an astonishing fact that developing countries, which have poor infrastructure, such as the poor condition of the pipeline network in which leaks and damage are present, consume as much as $75 \%$ more energy compared to countries with satisfactory infrastructure. On the other hand, we have examples of Israel and Singapore that treat as much as $87 \%$ and $50 \%$ of wastewater, respectively. Countries where drinking water is obtained by the desalination process consume significantly higher amounts of energy, and generally speaking desalination is the process that consumes the most energy compared to other processes in the urban water system. For comparison, the average value of energy used in the desalination process is 2.4 - $8.5 \mathrm{kWh} / \mathrm{m}^{3}$, while for example pumping of surface water requires $0.0002-1.74 \mathrm{kWh} / \mathrm{m}^{3}$, pumping of groundwater $0.37-1.44 \mathrm{kWh} / \mathrm{m}^{3}$, and wastewater treatment $0.38-1.122 \mathrm{kWh} / \mathrm{m}^{3}$ [16].

Renewable energy sources are energy sources that can be renewed by themselves and are available in unlimited quantities. These energy sources are consumed but only temporarily and are always renewed. They are also called alternative energy sources and their use is on the rise. Renewable energy sources include: wind energy, water energy, solar energy, hydrogen energy, geothermal energy, biomass energy, tidal energy, wave energy, and cold energy from space [15].

Renewable energy sources do not pollute the environment as non-renewable ones; however, they are still not completely clean. For example, burning biomass for energy production releases $\mathrm{CO}_{2}$ like fossil fuels. Apart from water energy, the use of renewable energy sources is associated with the problem of economic profitability (present low level of technological development) and small amounts of energy obtained [7]. However, it can be concluded that renewable energy sources simply have no alternative, in the near and distant future alike. In the long run, the development and use of renewable energy sources contribute to:

- diversifying energy production and safety of supply, 
Knezović, N., Rozić, Ž.

Sustainability of the urban water system using renewable energy resources

- reducing dependence on energy imports,

- reducing the environmental impact of fossil fuel use,

- increasing competitiveness, opening new jobs and developing entrepreneurship,

- encouraging the development of new technologies and the domestic economy as a whole and investing in rural areas, areas of special state concern, coastal areas, islands and the like [7].

\subsection{Renewable energy sources in the operation of the water supply system}

Solar energy is available every day of the year, and is therefore a significantly more acceptable and reliable energy source for local use. The quantity of solar energy outside the atmosphere is approximately constant, about $1366 \mathrm{~W} / \mathrm{m}^{2}$, and on the Earth's surface it is smaller as a result of geometric characteristics and filtration that takes place through the atmosphere in a space. So, energy from the sun can be generated every day everywhere on Earth, but with different intensities and durations. Although available only during the day while the sun is shining, due to constancy it is a more reliable local source than wind. Today, two types of solar generators are used: photovoltaic (PV) systems and thermal systems (TS) [10]. The PV system transforms solar energy into electrical energy. It is a very simple and easily applicable technological system.

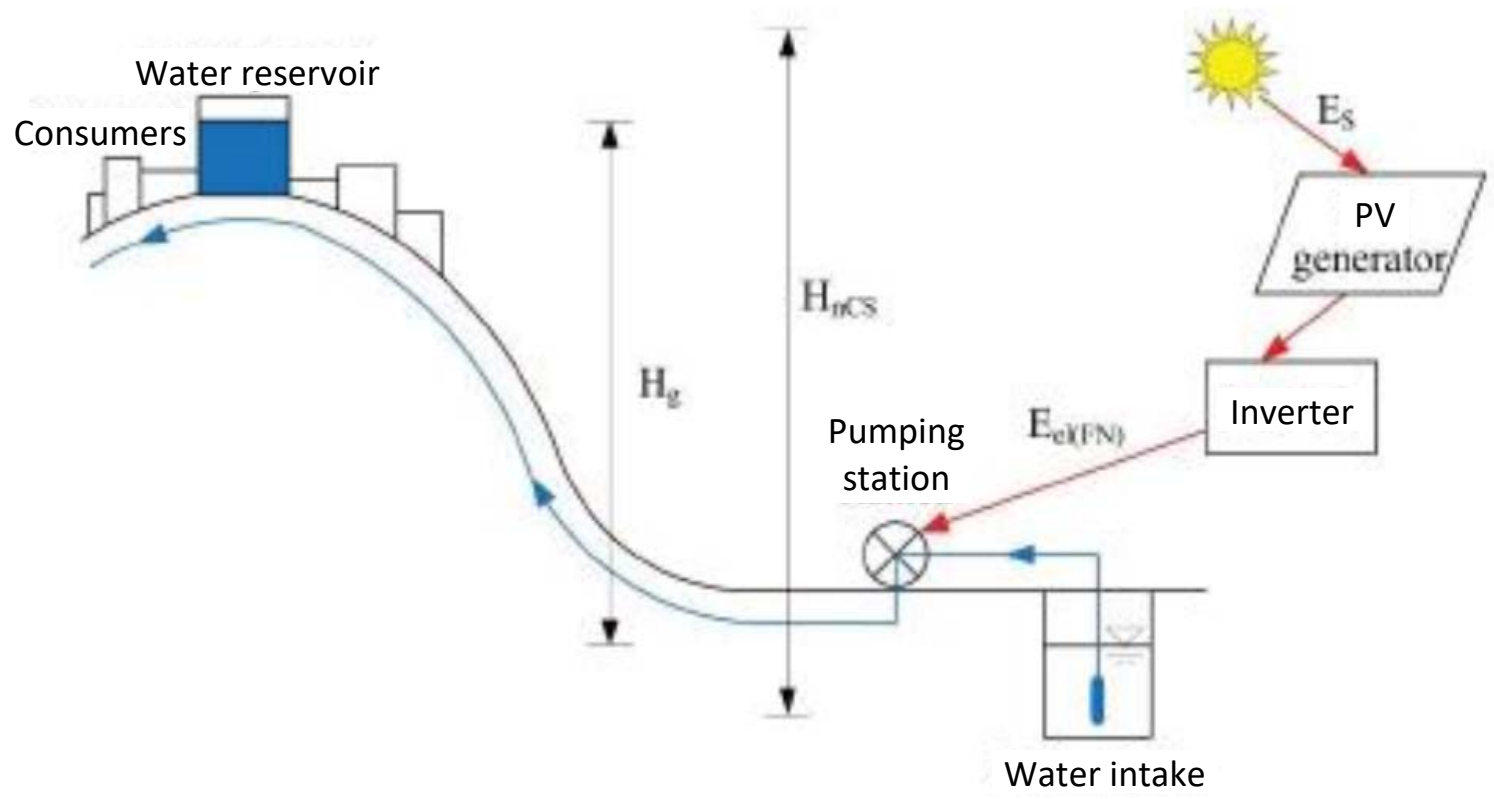

Figure 3. The concept of continuously supplying power to the water system [10]

In practice, the main elements of the conventional solar energy use concept are a photovoltaic generator of a certain capacity, an inverter and a battery, and accessories for improving the output characteristics of electrical energy. The batteries used to bridge the periods when the sun does not shine or is of insufficient intensity and duration compared to the requirements are the biggest problem of this system. That is why this solution is still not used for greater energy consumers, but only for smaller ones in isolated locations remote from the power grid [10]. However, if the need to install batteries can be avoided, then the possible applicability is significantly more favorable because the system is simpler and cheaper. This is the case of water pumping in water supply and sewage systems related to 
Knezović, N., Rozić, Ž.

Sustainability of the urban water system using renewable energy resources

the use of water reservoirs and retention basins. In these cases, reservoirs and retention basins function as energy storage because they balance input and output energy/water. Thus, whenever a pumping station is connected at the inlet or outlet to a water reservoir (clean or raw water, wastewater, mixed water or rainwater), the water reservoir can be used to bridge the period of operation when the sun does not shine or is not strong enough [10].

The system is dimensioned by the critical period method in the selected planning period. The critical period for selection of the power of the PV system, the capacity of the pumping station and the volume of the reservoir is different and depends on the balancing period. Based on past experience in the analysis of a solution of this kind, for water supply systems it is established that the winter period is critical for power of PV generators, due to low insolation, and the summer period is critical for water reservoirs, because of the highest water consumption [10]. This method and behavior of the system ensures high system operation safety because during the winter significantly higher available volume of water reservoir provides a reserve for all incident situations in relation to insufficient insolation, and in summer the PV system is significantly greater than necessary and makes it possible to pump over larger quantities of water if consumption increases or if insolation is lower [10]. The power of the PV system and the volume of the water reservoir are interdependent variables as functions of the balancing period. Extending the balancing period reduces the necessary power of the PV system and increases the volume of the water reservoir. Since the price of the PV system is significantly higher than the price of the water reservoir, it follows that it is more reasonable to use as long balancing periods as possible [10].

Based on this method, and in order to ensure current business operations, research on the fastest, most cost-effective, environmentally friendly and energy efficient solutions was conducted for electrical energy supply to water pumps for the water supply systems Ljubuški and Vrgorac [3]. The analysis showed that during 2017, the total electrical energy consumption for the Ljubuški system amounted to approximately 1.63 million $\mathrm{kWh}$. By installing photovoltaic solar panels, an amount of about 1.15 million $\mathrm{kWh}$ can be generated annually. This would cover about $70 \%$ of all electrical energy needs for water supply in Ljubuški and could save about 76,000 euros per year. Regarding the Vrgorac water supply system, the analysis showed a consumption of 1.81 million $\mathrm{kWh}$ during 2017 . Thanks to photovoltaic solar cells/panels, it is possible to produce about 1.54 million $\mathrm{kWh}$, which is about $85 \%$ of their electrical energy needs. Expressed by economic value, the total annual cost savings of the Vrgorac water supply system would amount to more than 100,000 euros per year [3].

\subsection{Renewable energy sources in the operation of wastewater treatment systems}

Although available in many locations, wind as a renewable energy source is generally rarely used on its own due to the nature of its action. It is characterized by unpredictable duration as well as the force with which it acts, which inevitably lead to interruptions in energy production, which results in unfavorable economic and technical characteristics [10]. However, in the world there are examples testifying to the use of wind as a renewable energy source in the operation of wastewater treatment systems [5]. One of such examples is located in Atlantic City. The system consists of five 397 feet (approximately $120 \mathrm{~m}$ ) high wind turbines with individual power of $1.5 \mathrm{MW}$, which are capable of producing a total of $7.5 \mathrm{MW}$ of electrical energy when operating at wind speeds of over 12 miles per hour. On average, this system produces approximately 19 million $\mathrm{kWh}$ per year. The wastewater treatment facility uses $2.5 \mathrm{MW}$ of energy per day. In ideal conditions, this means that the wind turbine system produces excess energy, which can be sold to the local grid, while in unfavorable 
Knezović, N., Rozić, Ž.

Sustainability of the urban water system using renewable energy resources

conditions, when the wind turbines do not produce enough energy, the system uses energy from the local grid. The conducted analysis shows that wind turbines produce energy that meets about $60 \%$ of the needs of the wastewater treatment plant, and that in the first 4 years of operation they have made savings of 2 million dollars [5].

Another example of using wind as a renewable energy source in the operation of wastewater treatment systems is also found in the USA, in the town of Browning, Montana. Rather than using large (397 ft), $1.5 \mathrm{MW}$ wind turbines from the above example, smaller (100 $\mathrm{ft}), 10 \mathrm{KW}$ wind turbines are used here. The system is designed so that all electricity produced by wind turbines is used for the operation of the wastewater treatment plant. One quarter of energy requirements of the wastewater treatment plant is met in this way [5].

Solar energy in the operation of wastewater treatment systems can be observed from different aspects.

- Use of solar energy as an energy source for plant operation

- Use of solar energy to dehydrate wastewater sludge and reduce water content in wastewater

- Use of solar energy in desalination processes [14].

An example in which a wastewater treatment plant primarily uses solar energy as its main energy source can be found in Oroville, California. This plant treats wastewater for about 15,000 households. In 2002, they decided to reduce costs and increase energy efficiency by using solar energy. A system consisting of 5,184 solar panels was installed and as such is the fifth largest in the USA. The system is designed to produce more energy during peak hours than the plant uses. This excess energy is distributed to the local power grid as a kind of credit for the period when solar panels do not produce electricity. The energy self-reliance of the plant is increased in this way. [5]

\section{CONCLUSION}

The application of the principles of sustainable development leads to the need to use renewable energy sources, improve their technical characteristics and functioning, and find new methods and technologies to finally abandon the use of non-renewable energy sources. To this end, it is necessary to pursue a policy based on strategic planning and the use of an integrated, not just economic approach, and a policy that works to develop education, raise general awareness and engage and work closely with experts from this, but also from other fields. [9] Numerous international agreements have been signed in accordance with such a policy, and one of the best known of them is the Kyoto agreement, which entered into force in 2004. With this protocol, all signatory countries commit to reduce greenhouse gases to 1990 levels, as well as to keep temperature increase below $2{ }^{\circ} \mathrm{C}$. The EU is adopting a package of energy measures that seeks to reduce greenhouse gas emissions by $80 \%$ by 2050. However, some countries, such as the USA, Canada, Australia, China and others, refuse to ratify some of these agreements because they believe they limit their economic development. [18]. On the other hand, there are countries, such as Italy, that introduce the impact of climate change as a compulsory subject in their education system [19]. However, renewable energy sources and energy efficiency will most certainly be the driving force of development in the $21^{\text {st }}$ century. We can see this in the example of the use of renewable energy sources such as solar energy, wind, biomass and the like in operation of the previously described urban water system. In addition to reducing the negative impacts of functioning of the urban water system on the climate, each of the new technologies reduces the greenhouse effect, increases the energy independence of the system, and leads to a new technological revolution. Replacing simple fossil-fuel-based technologies with more sophisticated and efficient machines, often closely connected with its electrical, electronic 
Knezović, N., Rozić, Ž.

Sustainability of the urban water system using renewable energy resources

and IT components, it is this technological revolution that is the foundation of economic growth and development, fully meeting all sustainability principles [2].

\section{REFERENCES}

1. Bošnjak, M.; Bućan, Ž.; Capek, K.; Jeličić P.: Mogući utjecaji klimatskih promjena na kvalitetu vode za ljudsku potrošnju; Hrvatske vode; 2019.

2. Duić, N.: Održivi razvoj energije, voda i okoliša (Sustainable Development of Energy, Water and Environmental Systems), Strojarstvo 2010.

3. Džeba, T.; Prskalo, M.: Održiva energija i upotreba u javnoj vodoopskrbi; Faculty of Civil Engineering, University of Mostar; 2019.

4. Đurin, B.: Održivost rada urbanog vodoopskrbnog sustava; University of Split, Faculty of Civil Engineering and Architecture Split; 2014.

5. Foley, K.: Wastewater treatment and energy: An analysis on the feasibility of using renewable energy to power wastewater treatment plants in Singapore; Massachusetts Institute of Technology, June 2010

6. Gereš, D.: Održivi razvoj vodnog gospodarstva; Sabor hrvatskih graditelja; Cavtat 2004.

7. Gvozdanović, A.: Obnovljivi izvori energije i gospodarstvo; Fakultet za ekonomiju i turizam Dr. Mijo Mirković Pula; 2016.

8. Halkijević, I.: Analiza održivosti vodoopskrbnih sustava; Dani sanitarne hidrotehnike; Zagreb 2016.

9. Loftus, Anne-Claire: Adapting Urban Water Systems to Climate Change (A handbook for decision makers at the local level); ICLEI European Secretariat GmbH; 2011.

10. Margeta J., Đurin B.: Mogućnosti primjene obnovljivih izvora energije za crpljenje vode u urbanom vodnom sustavu; 6. Hrvatska konferencija o vodama; Opatija, 2015.

11. Margeta, J.: Vodoopskrba naselja; University of Split, Faculty of Civil Engineering and Architecture Split; 2010.

12. Rozić, Ž.; Margeta, J.; Knezić, S.: Modeliranje urbanog vodnog sustava; Građevinar; 2007.

13. Šentija, B.: Upravljanje obnovom urbanog vodnog sustava; University of Split, Faculty of Civil Engineering and Architecture Split; 2015.

14. Young, S.; Ziyang, G.; Yuan, P.; Integration of Green Energy and Advanced EnergyEfficient Technologies for Municipal Wastewater Treatment Plants, International Journal of Environmental Research and Public Health, April 2019

15. https://hr.wikipedia.org/wiki/Obnovljivi_izvori_energije, access date: (20.03.2020)

16. https://www.researchgate.net/publication/304691555_Energy_consumption_for_water_ use_cycles_in_different_countries_A_review, access date: $(20.3 .2020)$

17. https://www.ekovjesnik.hr/clanak/2170/becko-postrojenje-za-prociscavanje-otpadnihvoda-postaje-elektrana, access date: (25.4.2020)

18. https://hr.wikipedia.org/wiki/Protokol_iz_Kyota, access date: (28.4 2020)

19. https://energis.ba/italija-postaje-prva-zemlja-na-svijetu-koja-uvodi-obavezno-klimatskoobrazovanje-u-skole/, access date: (26.4.2020) 